УДК 94(47):329.15 : 338.2(470.56-89)"1921/1928”

\title{
ДЕЙСТВИЯ ПАРТИЙНО-СОВЕТСКОГО АППАРАТА ОРЕНБУРГСКОЙ ГУБЕРНИИ ПО ВНЕДРЕНИЮ В ЖИЗНЬ ПРИНЦИПОВ НОВОЙ ЭКОНОМИЧЕСКОЙ ПОЛИТИКИ
}

\author{
(C) 2020 Ю.О. Куренкова
}

Оренбургский государственный педагогический университет

Статья поступила в редакцию 02.11.2020

\begin{abstract}
В статье оцениваются действия советской власти в Оренбургской губернии по внедрению в жизнь принципов новой экономической политики. Обозначены причины необходимости изменения экономической политики в стране и регионе. Приведены примеры мероприятий и форм работы партийно-советского аппарата и других институтов. Указаны приоритеты местной власти в отношении преобразования жизни крестьян. Выявлены трудности реализации нэпа в губернии на первом этапе. Описана реакция разных социальных групп на введение нэпа и отношение к нему. Сделан вывод о результатах работы партийно-советских органов по реализации нэпа к середине 1920-х гг. в Оренбуржье.

Ключевые слова: новая экономическая политика, крестьянство, Советская власть, партийный аппарат, Оренбургская губерния.
\end{abstract}

DOI: $10.37313 / 2658-4816-2020-2-4-36-43$

Новая экономическая политика Советской власти является неоднозначным историческим событием. Почти сто лет отделяют нас от ее официального провозглашения, и, несмотря на большой интерес историков к ней со времен «перестройки», существует немало неисследованных аспектов нэпа.

Во второй половине 1980-х - начале 1990х гг. ряд исследователей оценивали нэп как позитивное и перспективное действие Coветской власти. Связано это было с попытками обновления политического режима и поисками прогрессивных действий Советской власти в прошлом в противовес сталинизму и прочим негативным явлениям. Изучались достижения нэпа, нюансы проявления этой политики в разных секторах экономики и сферах общественной жизни. В конце XX - начале XXI века региональные исследователи активнее стали изучать внедрение принципов нэпа на местах, отражая разнообразие и неодинаковость реализации этой политики (например, С.А. Есиков,

Куренкова Юлия Олеговна, кандидат исторических наук, доцент кафедры истории России. E-mail: kpbicka@yandex.ru
В.А. Ильиных, И.В. Кочетков, В.А. Саблин и др.). Глубокое изучение кооперации 1920-х годов и других сущностных характеристик экономики СССР и социально-политических отношений привело ученых к более критическим оценкам нэпа вплоть до отрицания реализации этой политики по факту ${ }^{1}$.

В связи с этим нэп как историческая проблема не теряет своей актуальности, что приводит к необходимости составления более полной картины его реализации на местах. Одним из ключевых вопросов в этом разрезе становится изучение действий региональных органов власти по внедрению и реализации принципов нэпа. Вопрос можно рассматривать начиная от возможностей коммуникации центра и регионов в первой половине 1920-х до изучения состояния и социального состава работников местных органов власти, включая и их ментальные установки по отношению к Советской власти и нэпу в частности. Сам процесс усвоения и передачи установок и принципов новой экономической политики руководителями и работниками партийно-советского аппарата также вызывает интерес, однако 
есть региональные особенности источниковой базы в рассмотрении этой темы.

Причины введения нэпа подробно рассматривались в историографии. Кратковременное усиление политики «военного коммунизма» после окончания гражданской войны не привело к желаемым результатам. В.И. Ленин считал некоторое время продразверстку тем рычагом, с помощью которого можно будет быстрее восстановить разрушенное войной народное хозяйство. Это было его политическим просчетом. Затягивание с отменой продразверстки привело к крестьянским волнениям, породило Кронштадский мятеж, стало одной из причин голода 1921-22 гг.

Не избежало крестьянских волнений и Оренбуржье. Необходимо заметить, что волнения крестьянского населения начались здесь сразу после введения продразверстки, перерастая порой в крупные вооруженные столкновения. В 1920 году на территории губернии действовали вооруженные силы под руководством Сапожкова, Охранюка-Черского, Серова. Численность их отрядов составляла 3000 человек ${ }^{2}$.

По сути дела, вплоть до 1923 года осуществляли набеги на представителей Советской власти члены группы Серова, да и целый ряд других представителей вооруженной оппозиции.

Нестабильное территориально-административное положение Оренбургской губернии в этот период накладывало отпечаток на взаимодействие органов власти. С 1920 до 1925 года губерния входила в состав Киргизской АССР (КАССР), а Оренбург был ее столицей. С 7 июня 1922 г. в губернии было ликвидировано районное деление и восстановлены Оренбургский, Орский уезды и вновь создан Исаево-Дедовский (с 1923 г. - Каширинский) уезд ${ }^{3}$. Еще следует отметить низкий уровень делопроизводства и нехватку грамотных кадров в местных органах власти.

Кроме вооруженных выступлений, проходивших в границах губернии, в конце политики «военного коммунизма» и в начале нэпа в крае наблюдаются так называемые ложные выступления.
В докладной записке Оренбургского губкома в адрес центрального комитета партии сообщалось: «В станице Донецкой имело место крупное выступление казаков против продагентов» ${ }^{4}$. В Укреппункте Илецкой защиты отмечалось неудовлетворительное настроение населения на почве продовольственной разверстки ${ }^{5}$. Недовольство казачьего населения повсеместно отмечалось в губернии, но не только казаки его выражали.

В разных селах губернии отмечалось «враждебное настроение населения к Советской власти из-за непосильной продразверстки». В некоторых волостях были свои особенности, связанные с недоверием крестьянства Советской власти. Например, в Илецко-Буранной волости Оренбургского уезда местные чиновники упрекали казаков в реакционности и причастности к «дутовщине», хотя, по мнению партийных работников из Оренбурга, обследовавших волость, они (то есть казаки) близки крестьянству ${ }^{6}$. Однако недоверие уже возникло и сотрудничества в деле организации местного управления не получилось, скорее, появилась вражда.

В Покровском районе в ряде сел произошли выступления крестьян, организованные советами. Сельское население открыто высказывало недовольство политикой продразверстки. Политика «военного коммунизма» не отвечала и экономическим задачам государства, требовался совершенно новый подход к проблеме выбора пути развития России, было необходимо совершить крутой поворот от чрезвычайных мер периода гражданской войны к политике реализации интересов разных слоев общества в целом и производящих групп в частности, к политике национального согласия. В связи с этим изменилось содержание экономической политики государства, теперь предусматривалась многоукладная структура общества, рациональное сочетание разных форм собственности, использование рыночных, товарно-денежных отношений, экономических методов хозяйствования, поддержание адекватных отношений между центром и окраинами. 
Поначалу нэп воспринимался как новый подход к решению задачи укрепления «смычки» между городом и деревней - очень важной, но не единственной проблемы функционирования советского государства, поэтому предстояло прежде всего принять меры к улучшению экономического положения крестьян. В Обращении ВЦИК «Ко всему крестьянству» говорилось: «Трехлетняя тяжелая и разорительная война, которую вела Советская власть с царскими генералами, помещиками, закончилась победой рабочих и крестьян. Теперь настал момент уменьшить тяготы крестьянства. Отныне постановлением ВЦИК и СНК разверстка отменяется и вместо нее вводится натуральный налог на продукты сельского хозяйства» 7 .

Необходимо было пояснить временность действия продналога и особенности его взимания. «По мере того, как будет налаживаться наша промышленность, от успеха которой зависит судьба крестьянского хозяйства и по мере того, как будет расширяться ввоз из-за границы иностранных товаров в обмен на наше сырье, доля падающего на крестьянство натурального налога будет уменьшаться», ${ }^{8}$ - отмечалось в Обращении. Крестьяне, выполнявшие государственные обязательства, получали право свободно продавать и покупать оставшиеся у них излишки сельскохозяйственных продуктов. Одновременно государственные органы власти призывали крестьян к максимальной работе на пашне.

Декретом СНК от 28 марта 1921 года «O свободном обмене хлеба и фуража» назывались губернии, в их числе и Оренбургская, которым разрешался свободный обмен, продажа и покупка хлебных, зернофуражных продуктов, картофеля и семян, поэтому снимались все заградительные отряды, действовавшие в указанных губерниях, как на гужевых путях, так и на железнодорожных и водных путях сообщения 9

В подписанном 29 апреля 1921 года наркомом юстиции Д.И. Курским постановлении «O прекращении дел о нарушении разверстки и неплатеже чрезвычайного налога» по сути определялись два основных метода получения продовольствия у крестьян: натуральный налог и товарообмен. Они становились законными в связи с уже упомянутыми постановлениями ВЦИК. Смягчались либо изменялись и отменялись прежние юридические последствия за невыполнение разверстки. Таким образом, нэп стал не только экономической мерой, но и провозвестником нового формата отношений между государством и обществом в целом. Государственные власти оформляли продналог в новых не чрезвычайных юридических рамках. Кооперативы, выступавшие в качестве агентов Наркомпрода, осуществляли товарообмен также в новых юридических условиях. Хотя в Оренбургской губернии поначалу кооперативное движение развивалось медленно, и это требовало дополнительных усилий местных советских органов.

Сущность новой экономической политики начали разъяснять в местной прессе. Краевая газета «Степная правда» в течение весны и лета 1921 года поместила более десяти передовых статей с популярным изложением сущности нэпа. Новая экономическая политика государства широко обсуждалась в коллективах, о чем свидетельствуют архивные документы. Общее собрание граждан села Чернореченское Оренбургского уезда, заслушав обращение ВЦИК к крестьянству о замене продразверстки натуральным налогом, постановило: «Обращение ВЦИК приветствовать и считать такой переход целесообразным, дающим возможность быстрее поднять на должную высоту разрушенное хозяйство Советской России» ${ }^{10}$. В Илекском уезде 4 мая 1921 года, согласно решению крестьянской конференции, уездный исполком издал постановление, в котором говорилось: «Немедленно разрешить населению Илекского уезда свободный обмен, закупку и продажу хлебных зернофуражных продуктов, картофеля и сена» ${ }^{11}$. Очевидно, новые принципы соответствовали желаниям крестьян. Крестьянские конференции болееменее регулярно стали проводиться и стали формой легитимизации на местах постанов- 
лений власти и способом взаимодействия власти и общества.

Важной силой в утверждении нэпа были рабочие, которые в Оренбуржье со времен революции 1917 года активно о себе заявили. Коллектив завода «Орлес» 15 апреля 1921 года на общем собрании рабочих и служащих, заслушав доклад о новой экономической политике, постановил: «Одобрить повестку РСФСР в продовольственном вопросе, как неизменно направленную в интересах рабочих и крестьян» ${ }^{12}$. Однако не все профессиональные группы одобрили новую политику. В Петровском районе райком партии организовал дискуссию ответственных работников по вопросу о замене продовольственной разверстки натуральным налогом. Обсуждение показало, что одни (меньшинство) отстаивали продразверстку, другие - продналог ${ }^{13}$.

Некоторые рабочие также сомневались в правильности новой экономической политики. Например, рабочий лесопильного завода «Орлес» М. Зайкин в своей статье, опубликованной в газете «Степная правда», сомневался в целесообразности перевода предприятия на хозяйственный расчет.

Губернская партийная организация должна была одной из первых пропагандировать принципы нэпа, однако не все было гладко внутри нее. Несмотря на то, что к 1 июня 1921 года ее численность возросла по сравнению с 1919 г. почти в 6 раз, в последующие два года произошло ее сокращение. Это произошло из-за выхода из нее многих коммунистов, несогласных с политикой, провозглашенной на Х съезде РКП(б). В докладе инструктора Оренбургского губкома РКП(б) Логинова об итогах обследования Покровского райкома в августе 1921 г. сообщалось, что только в одном районе по причине несогласия с нэпом вышло из партии около 100 коммунистов, или 5\% состава районной организации ${ }^{14}$.

Примеры непонимания новой экономической политики привел в своем выступлении председатель губисполкома С. Теряхов на VI губернской конференции. Он подчеркивал, что необходимость нэпа не сразу осознается на местах. «Я не говорю только по районам и селам, но причисляю сюда и губернские организации. Ими тоже не сразу этот курс усваивается. Мы отмечаем растерянность товарищей, привыкших работать по прежним методам» ${ }^{15}$.

Планомерной целенаправленной работе партийной (большевистской) организации губернии по реализации принципов нэпа мешали организационная слабость, неприятие идей нэпа достаточно большой частью ее членов вплоть до руководителей губернского уровня. В их сознании поначалу господствовал мотив временности нэпа и возможности возврата к прежним привычным со времен продразверстки методам работы.

С установками политики «военного коммунизма», существовавшими в сознании этих партийцев, боролись путем разъяснительной работы. 10 июля 1921 года в Оренбурге состоялось собрание городской партийной организации, посвященное нэпу. На собрании с докладом о новой экономической политике выступил секретарь ЦКРКП(б) Е. Ярославский. В резолюции, принятой собранием, говорилось: «Собрание приветствует переход к нэпу и обязывает всех своих членов применить все свои силы, знания и опыт на изучение, и уяснение всей целесообразности новой экономической политики» ${ }^{16}$.

Подобные мероприятия были необходимы и для снижения градуса недовольства, и для реализации советской демократии, которая, несмотря на отсутствие реальных оппозиционных сил и сужение политического плюрализма, должна была отражать интересы народа, в первую очередь «трудящихся масс». Разные формы взаимодействия партийно-советского аппарата с населением отражали поиски властями наиболее удобных и результативных форм общения после «чрезвычайщины» периода Гражданской войны и «военного коммунизма». Заметны различия в реакции населения в городе и деревне на введение нэпа. Несмотря на то, что решался продовольственный вопрос, который обеспечивался во многом крестьянством, оно оставалось достаточно пассивным в реакции на новую политику, в отличие от горожан. В Оренбургской губернии отклик крестьян 
возникнет в 1924-25 гг., когда удастся восстановить разрушенное хозяйство.

Всю работу по внедрению принципов новой экономической политики можно разделить на несколько этапов. На первом этапе - весна - лето 1921 года - основы новых подходов к организации экономической жизни страны пытались осмыслить местные управленческие структуры. При этом можно выделить две группы управленцев. Одни из них (таких было меньшинство) сразу и без колебаний приняли идеи нэпа, понимая, что в противном случае речь может идти о ликвидации Советской власти. Эта категория партийных и советских работников совершенно искренне пыталась осмыслить и внедрить в жизнь новые принципы экономической жизни. Другое дело, что порой эти руководители партийных и советских органов сами не до конца осознавали те или иные установки центра. Причин здесь много, но одной из важнейших являлась недостаточная образованность. Другие сомневались в адекватности и результативности навязываемой центром политики, тем более что временность вводимых мер озвучивалась и руководителями государства.

Однако несмотря на это именно на первом этапе шла активная пропагандистская и организационная работа в массах. IX Bceроссийский съезд Советов в декабре 1921 года разработал «Наказ о хозяйственной работе», которым обязал местные органы улучшить снабжение крестьян товарами, необходимыми для подъема благосостояния. Рабочие организации обязаны были позаботиться о развитии отраслей промышленности, которые могли бы быстро удовлетворить потребности крестьянства.

Решения IX Всероссийского съезда Советов послужили серьезным стимулом к оживлению всей работы среди населения. Оренбургским губисполкомом была издана брошюра «Что сказал IX съезд Советов о развитии и укреплении сельского хозяйства». Местное крестьянство достаточно активно откликнулось на Решения IX съезда Советов. На проходивших конференциях выносились резолюции, одобрявшие решения съезда по подъему сельскохозяйственного производства, предлагались практические меры по их реализации. Крестьянская конференция Покровского района Оренбургской губернии, заслушав доклад о развитии сельского хозяйства, приняла резолюцию: «Выслать по волостям и селам руководителей, которые смогут разъяснить решения IX Всероссийского съезда Советов и дать правильные ответы на заданные крестьянами вопросы, вовлекая крестьянские массы в широкую самодеятельность как по улучшению своего, так и государственного благосостояния» ${ }^{17}$. Подобные крестьянские конференции пытались проводить в разных волостях, но уровень грамотности населения и желание взаимодействовать с властью были неодинаковы. Нередко такие конференции становились формальностью, при помощи которой местные партийцы могли отчитаться о проделанной работе, однако реальное участие непосредственно крестьян в них было незначительным.

Местные власти активно привлекали прессу и распространяли разнообразные печатные издания для разъяснения новой политики. В помощь агитаторам Губкумпросвет дополнительно переиздал брошюру «Деревня и натуральный налог» тиражом в 5 тысяч экземпляров ${ }^{18}$. Несколько номеров местных газет были полностью посвящены вопросу о необходимости выполнения продналога и его значению в условиях развивающейся республики. Часть газет распределялась между крестьянами бесплатно ${ }^{19}$.

Местные органы власти систематически информировали население о ходе продналоговой кампании, ежедневно помещая на страницах местных газет статьи, заметки и сводки, посвященные данному вопросу. Проводилась разъяснительная работа среди населения о важности своевременной сдачи продовольственного налога государству. Так, в газете «Завод и пашня» за период с июля по ноябрь 1922 года было опубликовано 49 статей агитационного характера, 150 заметок и 65 сводок о продналоге ${ }^{20}$. Газета «Степ- 
ная правда» в этот период часто публиковала материалы, посвященные голоду, однако заметки об организации продналоговой кампании и ее результатах, о товарообмене и его объемах и о прочих практиках нэпа регулярно помещались на ее страницах.

На почве голода нарастали анархические движения, и крестьян в первую очередь волновали вопросы обеспечения своих хозяйств посевным материалом и содержание семьи, что отмечалось в местных документах ${ }^{21}$. Поэтому в некоторых районах губернии наблюдались попытки кулацкого элемента овладеть руководящей ролью в сельских советах, но они натыкались на сопротивление бедняцкого крестьянства. Оно грозилось начать забирать зарытый у кулаков хлеб ${ }^{22}$. Такие настроения, связанные в первую очередь с необходимостью выживания, затрудняли адекватное донесение информации до сельчан о нэпе.

Активно принимались административные меры за сокрытие пашни. К осени 1922 года таких земель только в Оренбургской губернии было выявлено 57749 десятин, большая часть которых - 30733 десятины - приходилась на долю Каширинского уезда ${ }^{23}$. Эти факты говорят о недоверии крестьян Советской власти, учитывая опыт Гражданской войны и периода «военного коммунизма».

Проводилась серьезная работа по запрещению использования зерна на изготовление самогона. Для усиления борьбы с таким явлением Совнарком 20 декабря 1922 года принял постановление, направив его всем начальникам губмилиции, в котором говорилось: «Все штрафы, взимаемые в судебно-административном порядке за незаконное изготовление и хранение спиртных напитков, обращаются: 50\% от штрафа в качестве премирования для работников милиции. Лицам, способствующим этому обнаружению, в качестве премий выдавать 25\% и 25\% от штрафа должны поступать в бюджет местных исполкомов» ${ }^{24}$. Таким решением правительство стремилось привлечь общественность на борьбу не только с пьянством, но и на выполнение плана по продналогу. В отчетных документах сельских советов этого периода, в повестках заседа- ний часто встречается постановка вопроса о борьбе с самогоноварением и пьянством, т.е. не только милиция, но и партийные работники, и члены местных аппаратов управления включились в эту работу.

Однако следует отметить, что, несмотря на большую работу, проводимую в губерниях Южного Урала по своевременной сдаче налога государству, план был выполнен в Оренбургской губернии лишь к первому декабря 1922 года, т.е. с опозданием на 1 месяц ${ }^{25}$.

В какой-то мере несвоевременность сдачи продналога можно отнести к техническим недочетам, недостаточной организации этого дела в губернии. Например, в некоторых волостях Оренбургского уезда списки налогоплательщиков были перепутаны, в результате чего беднота была обложена налогом больше, чем кулаки и середняки. В Каширинском уезде вместо фактически засеянных 2-х десятин крестьянину пришлось платить за 5-6 десятин. Все это отрицательно сказалось на сроках уплаты налога ${ }^{26}$. Нехватка грамотных кадров, отдаленность территорий, несвоевременное сообщение информации о сборах были недочетами организации местной власти.

Вносили свою лепту и территориальные особенности края, они накладывали свой отпечаток на условия формирования и работы партийно-советского аппарата вообще и в деревне в частности. Сложно было выстроить их четкую соподчиненную систему, которая бы стабильно функционировала. Крестьянство могло не вникать в принципы районирования, вырабатываемые в центре, но влияние частых административно-территориальных изменений на деятельность органов местного управления оно видело и ощущало, в том числе в процессе реализации принципов нэпа.

Одной из важных форм реализации нэпа было распространение кооперативного движения в деревне. 21 августа 1921 г. в Оренбургской губернии был учрежден Оренгубселькредитсоюз. С 1 октября 1921 г. по 1 января 1923 г. количество кооператив- 
ных хозяйств достигло почти 50\% от всех хозяйств губернии ${ }^{27}$. Одной из целей крестьян в этот период становится получение как можно большего количества льгот: кредитов, семссуд. Для власти коммуны и сельхозартели были выгодны с точки зрения применения финансовых санкций и реализации хлебозаготовок в срок. Однако на первых порах такие формы организации не были популярны в деревне.

Во второй половине 1921 года В.И.Ленин предложил провести ряд организационных мер по обновлению продовольственных органов и обратил внимание Оренбургского губисполкома на необходимость улучшения работы налогового аппарата губернии, выразив уверенность, что эта трудная задача будет решена ${ }^{28}$. С учетом этих указаний на местах создавались инициативные группы по отбору лучших кадровых работ для включения в продовольственный аппарат.

К 1923 году, например, в Оренбургском продовольственном комитете рабочие составляли более 30\% против 2\% в 1921 году ${ }^{29}$. Многие рабочие направлялись в села для оказания помощи сельским продорганам в соответствии с планом заготовок сельскохозяйственной продукции. Оценить отсылку рабочих можно двояко: с одной стороны, это могло свидетельствовать о неэффективности реализации нэпа в деревне, значит, нужна была весомая поддержка в лице авторитетных людей, которыми и были рабочие как ведущий класс. Это действие в определенной мере станет предвестником акции «Лицом к деревне!» середины 1920-х гг. С другой стороны, из-за особенностей ситуации в губернии была необходима реальная помощь со стороны активных грамотных кадров в организации сбора продналога.

Несмотря на принятые меры сбор продналога осуществлялся с большими трудностями. Декрет СНК РСФСР от 15 июля 1921 года «Об ответственности за нарушение декретов о натуральных налогах» мог подкорректировать сложившееся положение. Инструкция Совнаркома РСФСР от 3 октября 1921 года по применению указанного декрета уточнила составы преступлений, по которым в судебном порядке рассматривались дела по несдаче налога.

Согласно выше названным нормативным документам дела о налоговых преступлениях стали рассматриваться народными судами и ревтрибуналами. Циркуляры Верховного трибунала от 12 ноября и 30 декабря 1921 года указывали на те основания, по которым ревтрибуналы должны были принимать к производству дела о неплатеже налогов: массовый отказ платить налог, повторное предъявление к сдаче недоброкачественных продуктов, умышленное сокращение посевных площадей в целях уклонения от внесения налога, продажа продуктов, подлежащих сдаче. Остальные дела подлежали рассмотрению в народных судах. В течение 1921 года активно применялись меры и административного, и судебного воздействия, но разразившийся голод затруднял этот процесс. Осложненная голодом ситуация требовала осторожных мер по внедрению нэпа, поэтому вынесенные судами решения нередко пересматривались.

Таким образом, как в центре, так и на местах представители органов управления под давлением тяжелой экономической ситуации, сложившейся после окончания гражданской войны, были вынуждены отказаться от принципов «военного коммунизма» и перейти к особому механизму хозяйствования, вошедшему в историю страны под названием «нэп». Разумеется, что подобные шаги партийно-советского аппарата вызывали неоднозначную реакцию как в самом аппарате, так и среди части населения, особенно горожан, которые были увлечены революционной фразеологией и в сознании которых укрепилась мысль о том, что строительство «светлого будущего» невозможно без временных потерь и конфликтов.

Неоднозначно приняли сначала новую политику крестьяне. Недоверие к власти, истощение войной и голодом заставляли их оставаться на фундаментальных установках сельской жизни. В период введения нэпа большая масса крестьян была вынуждена 
элементарно выживать. Партийно-советскому аппарату на местах приходилось искать способы и людей, способных донести до сельчан новые установки в экономической сфере. Профессионализм работников советского аппарата вызывал еще много вопросов и требовал совершенствования.

Однако, объективно оценивая сложившееся положение, партийное руководство страны, поддержанное наиболее вдумчивыми представителями советского и большевистского актива на местах, в том числе и в Оренбуржье, настояло на внедрении пусть и ограниченных принципов новой экономической политики в хозяйственную и социальную жизнь. Результаты восстановления хозяйства в Оренбуржье в середине 1920-х годов свидетельствуют об эффективной реализации принципов нэпа местной властью.

\section{ПРИМЕЧАНИЯ}

${ }^{1}$ См. например, работы: Гимпельсон Е.Г. Новая экономическая политика Ленина - Сталина. Проблемы и уроки (20-е годы ХХ в.) М., 2004; Давыдов А.Ю. Кооператоры советского города в годы нэпа. Между «военным коммунизмом» и социалистической реконструкцией. СПб., 2011.

${ }^{2}$ Сафонов Д.А. Великая крестьянская война 1920 -
1921 гг. и Южный Урал. Оренбург, 1999. С. 140. 3 Государственный архив Оренбургской области (далее - ГАОО). Ф. 261. Оп. 1. Д. 474. Л. $1160 б$.

${ }^{4}$ Сафонов Д.А. Великая крестьянская война 19201921 гг. и Южный Урал. Оренбург, 1999. С. 147.

${ }^{5}$ ГАОО. Ф. 261. ОП. 1. Д. 474. Л. 118.

${ }^{6}$ ГАОО. Ф. Р-1. ОП. 1. Д. 728. Л. 12.

${ }^{7}$ Известия. 1921. 23 марта.

${ }^{8}$ Известия. 1921. 23 марта.

${ }^{9}$ Известия. 1921. 29 марта.

${ }^{10}$ ГАОО. Ф.1. ОП. 1. ОП. 215. Л.23.

11 Там же. ГАОО. Ф.1. Оп. 1. Оп. 215. Л.23.

${ }^{12}$ Коммунар. 1921.7 апреля.

${ }^{13}$ Коммунар. 1921. 20 апреля.

${ }^{14}$ Оренбургский государственный архив социально-политической истории (далее - ОГАСПИ). Ф. 6002. Оп. 1. Д. 54. Л. 12.

${ }^{15}$ ОГАСПИ. Ф. 1. ОП. 1. Д. 214. Л.4.

16 Там же. Л. 5.

${ }^{17}$ ОГАСПИ. Ф.1. ОП. 1 Д. 326. Л. 43.

${ }^{18}$ ГАОО. Ф. 166. ОП. 1 Д. 1347. Л.10.

${ }^{19}$ ГАОО. Ф. 166. Оп.1. Д. 1347. Л. 11.

${ }^{20}$ Оренбургский рабочий. 1923. 14 января.

${ }^{21}$ ГАОО. Ф. Р-1. ОП. 1. Д. 236. Л. 21 об.

${ }^{22}$ ГАОО. Ф. Р-1. ОП. 1. Д. 236. Л. 22. Д. 376. Л. 246.

${ }^{23}$ ГАОО. Ф. 633. ОП. 3. Д. 1. Л. 33 об.

${ }^{24}$ Советское строительство Киргизии. 1923. №1.С. 77.

${ }^{25}$ ГАОО. Ф. 4. ОП. 1.Д. 10. Л. 29.

${ }^{26}$ ГАОО. Ф. 636. ОП 1. Д. 4. Л. 4-5.

${ }^{27}$ ГАОО. Ф. 1. ОП. 1. Д. 728. Л. 15.

${ }^{28}$ ГАОО. Ф. 1. ОП. 1. Д 209. Л. 183.

${ }^{29}$ ГАОО. Ф. 116. ОП. 1. Д 453. Л. 56.

\title{
ACTIONS OF THE SOVIET PARTY APPARATUS OF ORENBURG GOVERNMENT TO IMPLEMENT THE PRINCIPLES OF A NEW ECONOMIC POLICY INTO LIFE
}

\author{
(c) 2020 Y. O. Kurenkova
}

\section{Orenburg State Pedagogical University}

\begin{abstract}
The article evaluates the actions of the Soviet government in the Orenburg province to implement the principles of the new economic policy. The reasons for the need to change the economic policy in the country and the region are indicated. Examples of measures and forms of work of the Soviet party apparatus and other institutions are given. The priorities of local authorities in transforming the life of peasants are indicated. The difficulties of implementing NEP in the province at the first stage are revealed. The reaction of various social groups to the introduction of NEP and attitudes towards it are described. A conclusion is made about the results of the work of the Soviet party bodies on the implementation of NEP by the mid-1920s. in the Orenburg region.

Keywords: new economic policy, peasantry, Soviet power, party apparatus, Orenburg province. DOI: $10.37313 / 2658-4816-2020-2-4-36-43$
\end{abstract}

Yuliya Kurenkova, Candidate of History, Associate

Professor of the Department of Russian History.

E-mail: kpbicka@yandex.ru 